\title{
Efisiensi Usaha Agribisnis Bawang Merah sebagai Strategi Usaha dalam Mendukung Ketahanan Pangan Di Kabupaten Blitar
}

\section{The Efficiency of Shallot Agribusiness as a Business Strategy in Supporting Food Security in Blitar Regency}

\author{
Joko Gagung S., dan Mochamad Fadil \\ Politeknik Pembangunan Pertanian Malang \\ e-mail: jokojogas@gmail.com
}

\begin{abstract}
ABSTRAK
Tujuan Penelitian ini untuk mengetahui efisiensi budidaya bawang merah, menghitung produktivitas usahatani bawang merah, menghitung produktifitas budidaya bawang merah pada petani yang melakukan penanganan pasca panen dan yang tidak melakukan. Metode penelitian ini menggunakan metode survey yaitu wawancara langsung dengan responden, responden yang dimaksudkan adalah petani bawang merah. Teknik analisis yang digunakan dalam penelitian ini adalah teknik analisis statistik deskriptif. Analisis statistik deskriptif digunakan untuk menganalisis data dengan cara mendeskripsikan atau menggambarkan peran dari pelaku usaha bawang merah, dilaksanakan dengan penyajian data variabel dengan cara data ditabulasi kemudian dideskripsikannya. Analisis data yang digunakan adalah R/C ratio usahatani bawang merah. Setelah data di kumpulkan dari seluruh sampel, maka di lakukan tabulasi data berdasarkan aspek penanganan pasca panen. Hasil penelitian menunjukkan bahwa budidaya bawang merah adalah efisien dengan nilai rerata penerimaan $(0,3 \mathrm{Ha}) \mathrm{Rp}$. 41.590.800, Total biaya usahatani Rp. 15.370.483, laba Rp. 26.220.317, R/C ratio sebesar 2,71. Adapun produktifitas usahatani Bawang Merah sebesar 8557,78 $\mathrm{kg} / \mathrm{ha}$ masih memungkinkan untuk ditingkatkan. Sedangkan seluruh petani responden melakukan penanganan pasca panen sehingga perbedaan produktivitas petani yang tidak melakukan penanganan pasca panen dengan yang melakukan penanganan pasca pananen tidak dapat ditentukan.
\end{abstract}

Kata kunci : Efisiensi, Strategi, Agribisnis bawang merah

\begin{abstract}
The purpose of this study was to determine the efficiency of shallot cultivation, calculate the productivity of shallot farming, and calculate the productivity of shallot cultivation for farmers who carry out post-harvest handling and those who did not. This research method uses a survey method that is direct interviews with respondents, respondents who are intended are shallot farmers. The analysis technique used in this study is descriptive statistical analysis techniques. Descriptive statistical analysis is used to analyze data by describing the role of onion business actors, carried out by presenting variable data by means of tabulated data and then describing it. Analysis of the data used is the $R$ / C ratio of onion farming. After the data has been collected from all samples, the data tabulation is based on aspects of post-harvest handling. The results showed that shallot cultivation was efficient with an average value of acceptance $(0.3 \mathrm{ha})$ of $\mathrm{Rp}$. 41,590,800, Total
\end{abstract}


farming costs $R p .15,370,483$, profit of $R p .26,220,317, R / C$ ratio of 2.71. The productivity of Red Onion farming of $8557.78 \mathrm{~kg} / \mathrm{ha}$ is still possible to be improved. While all respondent farmers carried out post-harvest handling so that differences in productivity of farmers who did not carry out post-harvest handling with those who carried out post-harvest handling could not be determined.

Keywords: Efficiency, Strategy, Shallot Agribusiness

\section{PENDAHULUAN}

Bawang merah (Allium cepa) merupakan komoditas hortikultura yang memiliki peluang pasar yang besar. Sebagai tanaman rempah, bawang merah banyak digunakan sebagai bumbu masakan dan obat herbal. Produksi bawang merah propinsi Jawa Timur pada tahun 2010 sebesar 203.739 ton dan memberikan kontribusi sebesar $18 \%$ dari produksi bawang merah nasional (BPS, 2010). Sedangkan kebutuhan domestik terhadap konsumsi bawang merah sebesar 976.284 ton (konsumsi = 795264 ton; benih, ekspor dan industri = 119286 ton). Mengingat kebutuhan bawang merah untuk komsumsi harus tersedia sepanjang tahun dengan jumlah yang relatif stabil, maka diperlukan adanya pengaturan pola penanaman pada sentra produksi bawang merah. Turunnya produktifitas bawang merah dapat disebabkan karena gangguan organisme pengganggu tanaman ( OPT), yaitu hama, penyakit dan gulma.

Gulma merugikan tanaman dengan menjadi kompetitor tanaman dalam hal mendapatkan nutrisi, ruang dan cahaya. Selain itu gulma ganas juga mengeluarkan senyawa alelopat yang dapat meracuni tanaman. Kerugian budidaya tidak hanya disebabkan oleh penurunan produksi tanaman tetapi juga dengan membengkaknya biaya produksi. Peningkatan biaya produksi biasanya dialokasikan untuk tenaga kerja penyiangan dan pembelian herbisida.

Biaya tenaga kerja untuk penyiangan dapat diminimalisir dengan melakukan penyiangan pada waktu yang tepat sesuai dengan jenis gulma yang paling dominan serta fase pertumbuhan tanaman yang mengakibatkan penurunan produksi akibat pengaruh gulma atau pada periode kritis yaitu waktu dimana pertumbuhan tanaman rentan terhadap gangguan dari luar karena efek kompetisi dan alelopati dari gulma. Sektor pertanian saat ini tidak hanya ditujukan untuk mempertahankan dan memantapkan swasembada pangan khususnya beras namun mencakup pula peningkatan produksi pertanian secara luas dan menyeluruh, termasuk hasil hortikultura seperti bawang merah.

Keberhasilan produksi bawang merah tersebut tidak menjamin petani untuk mendapatkan pendapatan yang layak karena harga bawang merah selalu mengalami fluktuatif, bahkan kadang menjadi sangat murah, terutama pada saat panen raya. Hal tersebut disebabkan karena petani tidak selalu melakukan penanganan pasca panen.

Pengeringan yang masih mengandalkan sinar matahari menjadikan petani kebanyakan hanya melakukan pengeringan ketika pada musim kemarau. Selain di keringakan ada juga petani yang mengolah menjadi bahan olahan seperti bawang goreng.

Produk bawang merah mempunyai sifat bulky yang mudah rusak dan tidak tahan lama sehingga penanganan pasca panen sangat diperlukan sebagai upaya penyelamatan hasil dan peningkatan nilai suatu produk. Hasil penelitian dari Haryono (2004), di daerah Brebes menunjukan bahwa untuk mendapatkan pendapatan yang tinggi perlu di lakukan penanganan pasca panen. Penanganan pasca panen tersebut meliputi pengeringan, 
pengikatan, pembersihan, grading, pengemasan, penyimpapanan, pengangkutan, bahan kimia.

Strategi pengembangan agribisnis bawang merah pada lima tahun mendatang diarahkan pada pengembangan di lini on-farm dan off-farm. Pada off-farm sendiri di awali dengan perbaikan teknologi pengolahan untuk mendukung pengembangan industri hilir bawang merah (skala rumah tangga maupun industri), misalnya industri irisan kering, irisan basah/utuh, pickles/acar, bawang goreng, bubuk bawang merah, tepung bawang merah, minyak bawang merah. Namun demikian menurut Thamrin (2002), sistem agribisnis dalam pertanian Indonesia belum berjalan sesuai dengan harapan.

Penelitian ini bertujuan untuk mengetahui efisiensi usaha budidaya bawang merah, menghitung produktivitas Usahatani bawang merah, menghitung produktifitas budidaya bawang merah pada petani yang melakukan penanganan pasca panen dan yang tidak melalukan penanganan pasca panen.

\section{METODOLOGI}

\section{Desain Penelitian}

Penelitian ini dilakukan di Kabupaten Blitar Propinsi Jawa Timur, karena Kabupaten tersebut memiliki potensi meningkatkan pengembangan bawang merah dan memiliki sarana yang mendukung. Adapun obyek penelitian ini adalah besarnya input-output, kelayakan dan efisiensi usahatani bawang merah. Subyek penelitian adalah petani produsen bawang merah di kabupaten Blitar.

Penelitian ini didesain sebagai penelitian deskriptif, dimana penelitian disusun untuk memberikan gambaran secara sistematis tentang informasi ilmiah yang berasal dari subyek atau obyek penelitian.

Metode penelitian ini menggunakan metode survey yaitu wawancara langsung dengan responden, responden yang dimaksudkan adalah petani bawang merah.

\section{Sumber Data}

Data yang dikumpulkan dalam penelitian digolongkan dalam dua kategori yakni data primer dan data sekunder. Data primer diperoleh dari responden yaitu petani bawang merah, dari Kabupaten Blitar. Adapun untuk memperoleh data budidaya bawang merah digunakan pengumpulan data yaitu dengan wawancara langsung tentang input, output dan variabel lain yang diperlukan saat melakukan kegiatan budidaya bawang merah.

Kajian data sekunder diperoleh dari beberapa instansi yang terkait seperti Kantor Desa, Kantor Kecamatan, Dinas Pertanian dan lembaga lainnya yang terkait dengan penelitian yang bersifat mendukung dan memperdalam hasil.

\section{Metode Penarikan Sampel}

Penetapan lokasi dilakukan dengan pertimbangan bahwa Kabupaten Blitar merupakan suatu wilayah yang memiliki potensi untuk mengembangkan usaha budidaya bawang merah. Dari kabupaten tersebut diambil tiga kecamatan berdasarkan informasi dari dinas pertanian kabupaten Blitar. Penentuan responden dilakukan berdasarkan penunjukan sebagai produsen atau pengurus di kelompok tani masing-masing yang memiliki peran dalam melakukan budidaya bawang merah.

\section{Teknik Pengumpulan Data}

Insturmen untuk mendapatkan data adalah dengan menggunakan perangkat kuisioner terbuka dan tertutup. Kuisioner dibagikan kepada responden selanjutnya responden mengisi jawaban dalam kuisioner yang telah diterimanya. Ada dua macam bentuk kuisioner untuk responden syaitu kuesioner untuk menggali data petani sebagai produsen bawang merah dan data pasca panen. 


\section{Teknik Analisis Data}

Teknik analisis yang digunakan dalam penelitian ini adalah teknik analisis statistik deskriptif. Analisis statistik deskriptif digunakan untuk menganalisis data dengan cara mendeskripsikan atau menggambarkan peran dari pelaku usaha bawang merah, dilaksanakan dengan penyajian data variabel dengan cara data ditabulasi kemudian dideskripsikan. Analisis data yang digunakan adalah $\mathrm{R} / \mathrm{C}$ ratio Usahatani bawang merah . Setelah data di kumpulkan dari seluruh sampel, maka di lakukan tabulasi data berdasarkan aspek penanganan pasca panen.

\section{HASIL DAN PEMBAHASAN}

\section{Keadaan Responden}

Responden dari anggota sembilan kelompoktani yang berasal dari delapan desa. Desa, nama kelompoktani dan jumlah dapat dilihat pada tabel 2 .

Tabel 2. Nama Desa, Kelompoktani dan Jumlah Responden

\begin{tabular}{cccc}
\hline No & Desa & Kelompoktani & Persentase Responden \\
\hline 1 & Semen & Ngudi Lestari & 16,66 \\
2 & Darungan & Maju Makmur & 6,68 \\
3 & Tlogo & Suka Maju & 16,66 \\
4 & Karangsono & Ngudi Kaweruh & 16,66 \\
5 & Satriyan & Sumber Mulyo & 16,66 \\
6 & Plosorejo & Subur Makmur & 3,34 \\
7 & Maron & Sido Mulyo & 3,34 \\
8 & Maron & Dwi Manunggal & 3,34 \\
9 & Kresik & Nuju Makmur IV & 16,66 \\
\hline
\end{tabular}

Adapun responden berdasarkan usia dapat dilihat pada tabel 3 di bawah ini:

Tabel 3. Persentase Responden Berdasarkan golongan Usia

\begin{tabular}{ccc}
\hline No & Usia ( (Tahun) & $\begin{array}{c}\text { Responden } \\
(\%)\end{array}$ \\
\hline 1 & $21-36$ & 13,33 \\
2 & $37-51$ & 63,33 \\
3 & $52-67$ & 23,34 \\
\hline
\end{tabular}

Sedangkan persentase jumlah responden berdasarkan pengalaman berusahatani dapat dilihat pada tabel 4 di bawah ini:

Tabel 4.Persentase Responden Berdasarkan Pengalaman Berusahatani

\begin{tabular}{ccc}
\hline No & $\begin{array}{c}\text { Pengalaman } \\
\text { Berusahatani } \\
\text { (Tahun) }\end{array}$ & Responden (\%) \\
\hline 1 & $4-12$ & 36,6 \\
2 & $13-21$ & 33,4 \\
3 & $22-30$ & 30 \\
\hline
\end{tabular}

42 | Jurnal Agriekstensia Vol. 18 No. 1 Juli 2019

\section{Keadaan Usahatani Bawang Merah}

Sistem usahatani Bawang merah yang diterapkan dapat dilihat pada tabel 5 berikut ini:

Tabel 5. Persentase Responden Dan Sistem Usahatani Bawang Merah

\begin{tabular}{ccc}
\hline No & $\begin{array}{c}\text { Sistem } \\
\text { Usahatani } \\
\text { Bawang merah }\end{array}$ & $\begin{array}{c}\text { Persentase } \\
\text { Responden } \\
(\%)\end{array}$ \\
\hline 1 & Prapatan & 23,34 \\
2 & Alur & 10 \\
3 & Monokultur & 40 \\
4 & Bedengan & 16,66 \\
5 & Memakai Mulsa & 10 \\
\hline
\end{tabular}

Adapun jarak tanam yang dipakai oleh responden sebagaimana tabel 6 .

Tabel 6. Persentase Responden Dan Jarak Tanam Usahatani Bawang Merah

\begin{tabular}{ccc}
\hline No & $\begin{array}{c}\text { Jarak } \\
\text { Tanam }\end{array}$ & $\begin{array}{c}\text { Persentase } \\
\text { Responden }(\%)\end{array}$ \\
\hline 1 & $20 \times 20$ & 26,66 \\
2 & $25 \times 25$ & 10 \\
\hline
\end{tabular}


Efiensi Usaha Agribisnis Bawang Merah sebagai Strategi usaha

(Joko Gagung S., dan Mochamad Fadhil)

\begin{tabular}{cccc}
\hline 3 & $20 \times$ X 25 & 10 \\
4 & $15 \times$ X 20 & 16,66 \\
5 & 17 X 25 & 23,34 \\
6 & $15 \times$ X 15 & 13,34 \\
\hline
\end{tabular}

Sedangkan umur tanaman dipanen sebagaimana pada tabel 7 .

Tabel 7 : Persentase Responden Dan Umur Tanaman Bawang Merah Dipanen

\begin{tabular}{ccc}
\hline No & $\begin{array}{c}\text { Umur Tanaman } \\
\text { Dipanen (hari) }\end{array}$ & $\begin{array}{c}\text { Persentase } \\
\text { Responden } \\
(\%)\end{array}$ \\
\hline 1 & 75 & 3,34 \\
2 & 70 & 26,66 \\
3 & 65 & 16,66 \\
4 & 60 & 53,34
\end{tabular}

Adapun responden yang menjual hasil panen ke tengkulak sebanyak 26,66\%, ke pengepul sebanyak $60 \%$ dan ke pedagang sebanyak $13,34 \%$

\section{Pembiayaan Usahatani Bawang Merah}

Pembiayaan usahatani bawang merah meliputi biaya tidak tetap yang meliputi

Biaya bibit, pupuk, pestisida, dan penggunaan tenaga kerja. Sedangkan biaya tetap usahatani bawang merah meliputi sewa tanah, pajak, dan bunga modal. Adapun besarnya biaya tersebut dengan luas rata-rata 0,3 Ha sebagaimana pada tabel 8 .

Tabel 8 : Rerata Biaya, Usahatani Bawang Merah Per-Musim kemarau Per satuan Luas 0,3 Ha Tahun 2017 Di Kabupaten Blitar .

\begin{tabular}{rlrrr}
\hline No Uraian & & $\begin{array}{r}\text { Rerata Jumla } \\
(\mathrm{Kg}) / \mathrm{HKP}\end{array}$ & $\begin{array}{r}\text { Rerata Harga } \\
(\mathrm{Rp})\end{array}$ & \multicolumn{1}{c}{$\begin{array}{r}\text { Rerata Biaya } \\
(\mathrm{Rp})\end{array}$} \\
\hline 1 & Bibit & 265,4 & $38.966,67$ & 7.701 .280 \\
2 & Pupuk NPK & 50,83 & $3.673,33$ & 297.900 \\
3 & Pupuk ZA & 107 & 1.210 & $176.283,3$ \\
4 & Pupuk Ponska & 54,16 & 843,33 & $124.583,3$ \\
5 & Pupuk Petrogenik & 814,16 & 333,33 & $445.416,7$ \\
6 & Pupuk SP 36 & 77,88 & 1.160 & 148.500 \\
7 & Pupuk TSP & 31,9 & 15.150 & $106.333,3$ \\
8 & Pupuk KCl & 22,53333 & 1.950 & $112.726,7$ \\
9 & Pupuk Mutiara & 22,67 & $1.683,33$ & 187.250 \\
10 & TOTAL PUPUK & & & \\
11 & Total Pestisida & 84,72 & 48833,33 & $4.137 .339,06$ \\
12 & Tenaga Kerja & & & \\
& & & & 14.026 .832 \\
13 & TOTAL BIAYA & & & \\
& TETAP & & & 600.000 \\
14 & Sewa Tanah & & & \\
15 & Pajak & & & $1.343 .650,5$ \\
16 & Bunga Modal & & & 15.370 .483 \\
17 & TOTAL BIAYA TETAP & & & \\
18 & TOTAL & & & \\
\hline
\end{tabular}

Dari tabel 8 tersebut dapat dijelaskan sebagai berikut, bahwa jenis bibit, pupuk, pestisida yang digunakan bermacam-macam. Jenis varietas Bawang Merah yang digunakan 43 | Jurnal Agriekstensia Vol. 18 No. 1 Juli 2019 meliputi varietas Bauji, Bali Jumbo, Thailand dan Tajuk. Adapun persentase responden yang menggunakan bawang merah berdasarkan varietas dapat dilihat pada tabel 9. 
Tabel 9. Varietas Bibit Bawang Merah Yang Digunakan Responden

\begin{tabular}{ccc}
\hline No & Varietas Bawang Merah & Persentase Responden (\%) \\
\hline 1 & Bauji & 16,67 \\
2 & Bali Jumbo & 26,67 \\
3 & Thailand & 50 \\
4 & Tajuk & 6,66 \\
\hline
\end{tabular}

Dari tabel 9 tersebut dapat dilihat bahwa persentase responden banyak menggunakan varietas Thailand, karena diketahui potensi produktifitasnya yang paling tinggi dibandingkan varietas lainnya, yaitu untuk varietas Thailand $18-20$ ton/ha, varietas Bauji 14 ton/ha, varietas Tajuk 12-16 ton/ha.
Sedangkan pupuk yang digunakan meliputi pupuk organik, SP 36, ZA, KCl, Ponska, TSP, NPK dan Mutiara. Responden mengkombinasikan beberapa jenis pupuk tersebut. Persentase responden yang menggunkan masing masing jenis pupuk tersebut dapat dilihat pada tabel 10 .

\begin{tabular}{ccc}
\multicolumn{3}{c}{ Tabel $10:$ Persentase Responden Dan Jenis Pupuk Yang Digunakan } \\
\hline No & Jenis Pupuk Yang Digunakan & Persentase Responden(\%) \\
\hline 1 & Pupuk Kandang & 60 \\
2 & SP 36 & 66,67 \\
3 & ZA & 76,67 \\
4 & KCl & 33,33 \\
5 & Ponska & 36,67 \\
6 & TSP & 30 \\
7 & NPK & 56,67 \\
8 & Mutiara & 20 \\
\hline
\end{tabular}

Dari tabel 10 tersebut terlihat bahwa persentase responden yang besar adalah menggunakan pupuk yang sudah umum dan tersedia secara lokal.

Tabel 11 : Jenis Pestisida dan Persentase Responden Yang Menggunakan

\begin{tabular}{ccc}
\hline No & Jenis Pestisida & Persentase responde(\%) \\
\hline 1 & Antracol & 60 \\
2 & Daconil & 56,67 \\
3 & Perekat & 36,67 \\
4 & Metindo & 33,33 \\
5 & Lain-lain (17 jenis ) & $3,33-16,67$ \\
\hline
\end{tabular}

Dari tabel 11 tersebut terlihat bahwa pestisida yang banyak digunakan responden adalah jenis pestisida yang umum dan banyak tersedia pasar.berbagai jenis pestisida. Disamping itu responden juga mengkombinasikan beberapa jenis pestisida. Persentase responden yang mengkombinasikan 2 jenis, 4 jenis, 6 jenis, 8 jenis, dan 10 jenis pestisida masing-masing 44 | Jurnal Agriekstensia Vol. 18 No. 1 Juli 2019
Adapun penggunaan pestisida ada 21 macam, sedangkan yang banyak digunakan oleh responden dapat dilihat 11 .

berturut-turut sebagai berikut : $6,66 \%$, $13,32 \%, 20 \%, 26,64 \%$, dan $33,3 \%$.

Sedangkan tenaga kerja yang bekerja dalam usahatani Bawang Merah ini menggunakan alat -alat seperti handtraktor, cangkul, cultivator, handsprayer, gembor, dan koret. Dan Biayanya sudah inklud dalam penggunaan tenaga kerja, sehingga tidak dihitung penyusutannya. 
Menurut Suratiyah (2006:67) faktorfaktor yang mempëngaruhi besarnya biaya dan pendapatan dapat dibagi kedalam dua golongan, yaitu:

(1) Faktor Internal

Faktor internal meliputi umur petani, pendidikan, pengetahuan, pengalaman, keterampilan, jumlah tenaga kerja keluarga, luas lahan dan modal. Ditinjau dari segi umur, semakin tua akan semakin berpengalaman sehingga semakin baik dalam mengelola usahataninya. Namun disisi lain semakin tua semakin menurun kemampuan fisiknya sehingga semakin memerlukan bantuan tenaga kerja, baik dalam keluarga maupun luar keluarga tani. Pendidikan, terutama pendidikan non formal akan membuka cakrawala petani, menambah keterampilan dan pengalaman petani dalam mengelola usahataninya. Jumlah tenaga kerja dalam keluarga akan mempengaruhi langsung pada biaya. Semakin banyak menggunakan tenaga kerja keluarga semakin sedikit biaya yang dikeluarkan untuk mengupah tenaga kerja luar keluarga. Namun demikian, ada pekerjaan atau kegiatan tertentu mengejar waktu sehubungan dengan iklim maka harus meminta bantuan tenaga kerja luar yang berarti harus mengeluarkan biaya. Petani lahan sempit dengan tenaga kerja keluarga yang tersedia, dapat menyelesaikan pekerjaan usahataninya tanpa menggunakan tenaga kerja luar yang diupah. Dengan demikian, biaya per usahatani menjadi rendah. Namun jika lahannya luas maka diperlukan tenaga kerja dari luar sehingga biaya usahatani menjadi lebih tinggi. Modal yang tersedia berhubungan langsung dengan peran petani sebagai manager dan juru tani dalam mengelola usahataninya. Jenis komoditas yang akan diusahakan tergantung modal karena ada komoditas yang padat modal sehingga memerlukan biaya yang cukup tinggi untuk mengusahakannya. Demikian pula seberapa besar tingkat penggunaan faktor produksi tergantung pada modal yang tersedia. Sebagai juru tani harus tahu persis banyaknya masing-masing faktor produksi yang diperlukan. Oleh karena itu biasanya petani sebagai manager tidak dapat menyediakan dana maka terpaksa penggunaan faktor produksi tidak sesuai dengan ketentuan yang seharusnya. Akibatnya produksi rendah dan pendapatan juga rendah (Suratiyah, 2006:68).

(2) Faktor eksternal

Sedangkan faktor eksternal terdiri dari ketersediaan input dan harganya, permintaan output dan harganya (Suratiyah, 2006: 67).

Faktor eksternal dari segi faktor produksi (input) terbagi dalam dua hal, yaitu ketersediaan dan harga, dimana kedua faktor tersebut tidak dapat dikuasai oleh petani sebagai individu dengan sejumlah dana tertentu yang tersedia. Namun jika faktor produksi berupa pupuk tidak tersedia atau langka dipasaran maka petani akan mengurangi penggunaan faktor produksi. Demikian pula jika harga pupuk sangat tinggi bahkan tidak terjangkau, semua itu akan berpengaruh pada biaya, produktivitas dan pendapatan usahatani.

\section{Penerimaan Usahatani Bawang Merah}

Adapun Rerata Produksi , harga bawang merash dan Penerimaan, Usahatani Bawang merah PadaMusim kemarau Tahun 2017 di Kabupaten Blitar Sebagaimana tabel 12. 
Tabel 12 : Rerata Produksi, Harga dan Penerimaan, Usahatani Bawang

Merah Per-Musim kemarau Per satuan Luas 0,3 Ha Tahun 2017 Di

Kabupaten Blitar.

\begin{tabular}{ccc}
\hline No. & Uraian & Nilai \\
\hline 1 & Rerata Produksi (kg) & $2.567,333$ \\
2. & Rerata Harga (Rp per kg) & 16.200 \\
3 & Rerata Penerimaan ( Rp/0,3 Ha ) & 41.590 .800 \\
\hline
\end{tabular}

Dari tabel 12 tersebut dapat dipahami bahwa produktifitasnya sebesar $8557,78 \mathrm{~kg} / \mathrm{ha}$ masih dibawah potensi produktifitas varietas terendah yaitu varietas Tajuk sebesar 9000 $\mathrm{kg} / \mathrm{ha}$. .Dari segi produksi (output), jika permintaan produksi tinggi maka harga ditingkat petani tinggi pula sehingga dengan biaya yang sama maka petani akan memperoleh pendapatan yang tinggi pula. Sebaliknya jika petani berhasil meningkatkan produksi, tetapi harga turun maka pendapatan petani akan turun pula (Suratiyah, 2006:69).

Tabel 13: Rerata Penerimaan, Total Biaya, Keuntungan dan R/C Ratio Usahatani Bawang Merah Per-Musim kemarau Per satuan Luas 0,3 Ha Tahun 2017

Di Kabupaten Blitar.

\begin{tabular}{ccc}
\hline No. & Uraian & Nilai (RP) \\
\hline 1 & Rerata Penerimaan ( 0,3 Ha ) & 41.590 .800 \\
2. & TOTAL BIAYA USAHATANI & 15.370 .483 \\
3 & Laba & 26.220 .317 \\
4 & R/C Ratio & 2,71 \\
\hline
\end{tabular}

Dari tabel 13 tersebut di atas, bahwa $\mathrm{R} / \mathrm{C}$ ratio dan Laba sangat terkait dengan faktor manajemen. Manajemen usahatani sangat diperlukan terkait dengan perencanaan, pengelolaan dan pengambilan keputusan dalam usahatani, baik melalui pertimbangan ekonomi, teknis maupun sosial agar produk yang dihasilkan memberikan pendapatan yang optimal. Petani sebagai juru tani harus dapat melaksanakan usahataninya dengan sebaikbaiknya, yaitu penggunaan faktor produksi dan tenaga kerja secara ëfisien sehingga akan diperoleh rnanfaat yang setinggi-tingginya (Suratiyah, 2006:69).

Dalam pelaksanaannya sangat diperlukan berbagai informasi tentang kombinasi faktor produksi dan informasi harga baik harga faktor produksi maupun produk. Dengan bekal informasi tersebut petani dapat segera mengantisipasi perubahan yang ada agar tidak salah pilih dan merugi (Suratiyah, 2006:69).

46 | Jurnal Agriekstensia Vol. 18 No. 1 Juli 2019

\section{KESIMPULAN DAN SARAN}

\section{Kesimpulan}

Dari hasil dan pembahasan diatas maka dapat disimpulkan bahwa efisiensi budidaya Bawang merah adalah efisien dengan nilai R/C ratio sebesar 2,71. Adapun produktifitas usahatani Bawang Merah sebesar 8557,78 $\mathrm{kg} / \mathrm{ha}$ masih memungkinkan untuk ditingkatkan. Sedangkan seluruh petani responden melakukan penanganan pasca panen sehingga perbedaan produktivitas yang tidak melakukan pasca panen dengan yang melakukan tidak dapat ditentukan.

\section{Saran}

Karena usahatani Bawang merah sangat menguntungkan dan mempunyai $\mathrm{R} / \mathrm{C}$ ratio yang tinggi, maka strategi mencari alternatif penggunaan faktor-faktor produksi yang efisien dan usaha-usaha peningkatan 

(Joko Gagung S., dan Mochamad Fadhil)

produktifitas melalui penggunaan varietas berpotensi tinggi dapat digunakan sebagai strategi pengembangan usaha budidaya Bawang Merah dalam mendukung kedaulatan pangan di Kabupaten Blitar.

\section{DAFTAR PUSTAKA}

Haryono Ludi. 2004. Studi kompertif pendapatan dan keuntungan antara petani pasca Panen dan petani tanpa pasca panen pada tanaman bawang merah di Desa Banjar
AnyarKecamatan Brebes Kabupaten Brebes. Skripsi. UMY

Komar, N, Rakhmadiono,S, \& kurnia, L. (2001). Teknik Penyimpanan Bawang Merah. Jurnal Teknologi Pertanian, 2(2), 79 -95

Rahayu Estu dan Berlian Nur.1999. Bawang merah. PT Penebar Swadaya. Jakarta

Suratiyah, K. 2006. Ilmu Usaha Tani. Penebar Swadaya. Jakarta 